\title{
Plasma leucocyte elastase concentrations in smokers
}

\author{
C R K Hind, H Joyce, G A Tennent, M B Pepys, N B Pride
}

\begin{abstract}
The associations between cigarette smoking, plasma leucocyte elastase concentration, peripheral leucocyte count and $F E V_{1}$ were examined in 148 men, 72 of whom were current cigarette smokers, 40 of whom were ex-smokers, and 36 who had never smoked. All men were part of a long-term survey. Smokers had significantly higher plasma leucocyte elastase concentrations than ex-smokers or those who had never smoked. Mean current $F E V_{1}$ was lower, and the annual decline in $F E V_{1}$ in the preceding 10 years was faster in smokers than the other two groups. A few smokers had slight increases in serum C-reactive protein concentrations. Although peripheral blood leucocyte counts were higher in smokers than in non-smokers or exsmokers, no association was found in any of the three groups of men between plasma elastase concentration and peripheral leucocyte count, nor between either of these two variables and annual decline in $F E V_{1}$ or current level of $F E V_{1}$. There was also no relation between plasma elastase concentration and reported daily cigarette consumption or mixed expired carbon monoxide in smokers.

The results indicate that some male smokers have increased in vivo release of elastase from peripheral blood neutrophils at a time when there is no evidence of acute infection. Because leucocyte elastase is a strong candidate for pulmonary tissue damage, further studies of the mechanisms that increase plasma concentrations are indicated.
\end{abstract}

Cigarette smoking is a major risk factor for the development of progressive airflow obstruction and emphysema. ${ }^{1}$ There is considerable evidence that neutrophils may be important in mediating lung damage induced by smoking. Thus current smokers have higher circulating leucocyte counts ${ }^{2,3}$ and bronchoalveolar lavage (BAL) neutrophil counts ${ }^{4}$ than ex-smokers or non-smokers, and there is an inverse correlation between circulating leucocyte count and one second forced expiratory volume $\left(\mathrm{FEV}_{1}\right)$ and forced vital capacity (FVC). ${ }^{3}$ In experimental studies in hamsters four hours' exposure to cigarette smoke causes extensive recruitment of leucocytes into the airway walls. ${ }^{5}$ Because elastase can cleave many struc- tural and soluble proteins, ${ }^{67}$ numerous authors have postulated that it has an important role in the development of emphysema. In vitro release of elastase stored in the granules of polymorphonuclear leucocytes in response to stimuli such as zymosan is similar from the neutrophils of smokers and non-smokers ${ }^{8}$; but incubation of neutrophils with cigarette smoke condensate results in increased in vitro release of elastase. ${ }^{9}$ Furthermore, increased in vitro elastase activity has been shown in cell-free BAL fluids of healthy smokers. ${ }^{10}$

The availability of a simple procedure for the estimation of the human leucocyte elastase $\alpha_{1}$ proteinase inhibitor complex, ${ }^{11}$ the form in which the bulk of the released enzyme circulates in the plasma, facilitates further investigation of in vivo elastase release. Although one previous study found no differences between smokers and non-smokers in plasma leucocyte elastase concentrations, ${ }^{12}$ those studied were all healthy volunteers and their lung function was not measured. We measured plasma leucocyte elastase concentrations and circulating neutrophil counts in groups of cigarette smokers, ex-smokers and life-long non-smokers whose lung function had been prospectively documented over 10 years.

\section{Methods}

We studied 148 Caucasian men working in west London who were originally recruited in 1974 for a prospective study of lung function. All the selected men had consistent smoking habits as checked on several occasions by questionnaire and measurement of mixed expired carbon monoxide and plasma cotinine, the major metabolite of nicotine with an average elimination half-life of 20 hours. The men were divided into three groups: (1) 36 life-long nonsmokers; (2) 40 ex-smokers who had stopped smoking seven or more years earlier; and (3) 72 current cigarette smokers. At the time of study 18 of these men smoked up to 15 cigarettes/day, 25 men smoked 16-25 cigarettes/day, and the remaining 29 men smoked more than 25 cigarettes/day. The mean ages of these subgroups all lay between 46.4 and $52 \cdot 6$ years (table).

All men had a normal chest radiograph. None gave a history of asthma or other chest disease, although some had chronic cough and expectoration. Blood samples were only taken if the subject had had no symptoms of a respiratory or other infection in the preceding six weeks. The men were not asked to modify their smoking habits on the day of testing. On
Correspondence to: Dr N B Pride

Accepted for publication 23 October 1990 
Smoking habit, peripheral blood leucocyte count, plasma leucocyte elastase concentration and spirometry

\begin{tabular}{|c|c|c|c|c|c|c|}
\hline Smoking habit & $\begin{array}{l}\text { No of } \\
\text { subjects }\end{array}$ & $\begin{array}{l}\text { Age } \\
\text { (years) }\end{array}$ & $\begin{array}{l}\text { Leucocyte count } \\
\left(\times 10^{9} / l\right)\end{array}$ & $\begin{array}{l}\text { Plasma elastase } \\
(\mu g / l)\end{array}$ & $\begin{array}{l}F E V_{1} \\
\text { (\% predicted) }\end{array}$ & $\begin{array}{l}\triangle F E V_{1} \\
\left(\mathrm{ml} . \text { year }^{-1} \cdot m^{-3}\right)\end{array}$ \\
\hline $\begin{array}{l}\text { Non-smokers } \\
\text { Ex-smokers } \\
\text { Current cigarette smokers } \\
\leqslant 15 / \text { day } \\
16-25 / \text { day } \\
>25 / \text { day }\end{array}$ & $\begin{array}{l}36 \\
40 \\
72 \\
18 \\
25 \\
29\end{array}$ & $\begin{array}{l}46 \cdot 4(10 \cdot 0) \\
50 \cdot 8(10 \cdot 9) \\
51 \cdot 1(10 \cdot 4) \\
52 \cdot 6(6 \cdot 8) \\
51 \cdot 6(9 \cdot 6) \\
49 \cdot 8(12 \cdot 9)\end{array}$ & $\begin{array}{l}6 \cdot 58(1 \cdot 66) \\
6 \cdot 08(1 \cdot 11) \\
8 \cdot 84(2 \cdot 30) \\
8 \cdot 91(2 \cdot 84) \\
8 \cdot 55(2 \cdot 16) \\
9 \cdot 04(2 \cdot 01)\end{array}$ & $\begin{array}{r}98 \cdot 7(31 \cdot 3) \\
84 \cdot 7(37 \cdot 1) \\
131.9(70 \cdot 9) \\
136 \cdot 5(62 \cdot 8) \\
119 \cdot 3(58 \cdot 1) \\
139.9(85 \cdot 1)\end{array}$ & $\begin{array}{r}115 \cdot 6(14 \cdot 3) \\
108 \cdot 6(15 \cdot 7) \\
96 \cdot 5(18 \cdot 2) \\
95 \cdot 5(18 \cdot 8) \\
99 \cdot 6(14 \cdot 9) \\
94 \cdot 3(20 \cdot 0)\end{array}$ & $\begin{array}{l}4 \cdot 40(4 \cdot 18) \\
5 \cdot 71(4 \cdot 48) \\
8 \cdot 43(6 \cdot 11) \\
7 \cdot 69(4 \cdot 73) \\
7 \cdot 62(5 \cdot 90) \\
9 \cdot 59(7 \cdot 00)\end{array}$ \\
\hline
\end{tabular}

Values are mean (SD).

$\star \triangle \mathrm{FEV}_{1}=$ annual rate of decline in $\mathrm{FEV}_{1}$ over preceding 10 years.

arrival the number of cigarettes smoked that day and the interval from completing their last cigarette were recorded and mixed expired carbon monoxide measured. The lack of a coincident disease likely to raise the plasma elastase concentration (such as infection) was subsequently confirmed by the normal serum C-reactive protein concentration $(<10 \mathrm{mg} / \mathrm{l})$ found in 141 of 148 subjects. ${ }^{13-15} \mathrm{Six}$ of the remaining subjects had values for serum creactive protein of $11-16 \mathrm{mg} / 1$ and one of $39 \mathrm{mg} / 1$.

All men gave informed consent and the procedure was approved by the research ethics committee of the Royal Postgraduate Medical School.

\section{COLLECTION OF BLOOD SAMPLES}

Venous blood samples were obtained from each person for measurement of the white cell count and plasma leucocyte elastase concentration. For the plasma samples, blood was drawn in EDTA and immediately kept at $4^{\circ} \mathrm{C}$ until the plasma was separated by centrifugation at $1000 \times g$ for 10 minutes at $4^{\circ} \mathrm{C}$. Separation was always performed within one to three hours of sample collection to minimise in vitro neutrophil degranulation. ${ }^{11}$ The upper third of the plasma was carefully aspirated and then stored in aliquots at $-20^{\circ} \mathrm{C}$ before assay. Extensive preliminary tests on samples from over 200 subjects established that with the present procedure there was no correlation between plasma leucocyte elastase and the circulating total leucocyte or neutrophil count.

ASSAYS

Leucocyte elastase concentration was determined by a commercial solid phase enzyme immunoassay, performed precisely according to the manufacturer's instructions (E Merck, D-6100 Darmstadt-1, Germany). The method depends on uptake of the elastase $\alpha_{1}$-proteinase inhibitor complex, the form in which the bulk of leucocyte elastase circulates in the plasma, by immobilised anti-elastase antibodies, and their detection by enzyme-labelled anti- $\alpha_{1}-$ proteinase inhibitor antibodies. Inter- and intra-assay coefficients of variation were $10 \%$ or less, and the lower limit of sensitivity of the assay was $13 \mu \mathrm{g} / 1$. Among normal controls (in whom smoking habits were not recorded) the mean leucocyte elastase concentration measured by this assay was reported as being $86.5 \mu \mathrm{g} / 1$ (range 58-115). ${ }^{11}$

Total white cell counts were performed with a Hemalog $\mathrm{D}$ automated analyser (Technicon Instruments).
LUNG FUNCTION

Forced expiratory volume in one second $\left(\mathrm{FEV}_{1}\right)$ was measured using a dry bellows spirometer on the day of blood sampling and compared with predicted values. ${ }^{16}$ The current value was compared with the value obtained in the survey 10 years before and the annual decline in $\mathrm{FEV}_{1}$ over this 10 year period calculated using the height-corrected difference in $\mathrm{FEV}_{1}$ values $\left(\triangle \mathrm{FEV}_{1} /\right.$ year $^{-1}$ expressed as ml. $\mathrm{m}^{-3}$.year ${ }^{-1}$ ).

Differences between the blood leucocyte counts and plasma elastase concentrations were determined by the Mann-Whitney $U$ test (the non-parametric equivalent of the two sample $t$ test). Correlations between different variables were examined using Spearman's rank correlation coefficient.

\section{Results}

EFFECT OF SMOKING HABIT ON PLASMA ELASTASE CONCENTRATIONS AND LEUCOCYTE COUNTS

Mean plasma elastase concentration in smokers was significantly higher than in ex-smokers $(\mathrm{p}<0.001)$ or non-smokers $(\mathrm{p}<0.05)$, with some smokers showing greatly increased concentrations (table, figure). There was no significant difference in elastase concentration between non-smokers and ex-smokers ( $p=$ 0.056 ). As expected, the average number of blood leucocytes was also significantly higher in smokers than in non-smokers (table) ( $\mathrm{p}<$ $0.001)$ or ex-smokers $(p<0.001)$, again with no significant differences between non-smokers and ex-smokers. Mixed expired carbon monoxide at the time of blood sampling was increased in smokers, averaging $7 \cdot 6,12 \cdot 8$, and $16.0 \mathrm{ppm}$ in smokers who consumed $\leqslant 15,16$ 25 , and $>25$ cigarettes/day, respectively. In the smokers there was no correlation between the reported daily number of cigarettes smoked or mixed expired carbon monoxide and the increase in either the plasma elastase concentration or leucocyte count. There was no significant correlation in any of the three groups between the plasma elastase concentrations and leucocyte counts (smokers: $r=0 \cdot 19$; ex-smokers: $r=0 \cdot 18$; non-smokers: $r=0.09)$.

\section{SPIROMETRY}

At the time of study, $\mathrm{FEV}_{1}$ was significantly lower in smokers (table) than in non-smokers $(p<0.001)$ and ex-smokers $(p=0.001)$. Over the preceding 10 years, smokers had shown a significantly greater decline in height- 


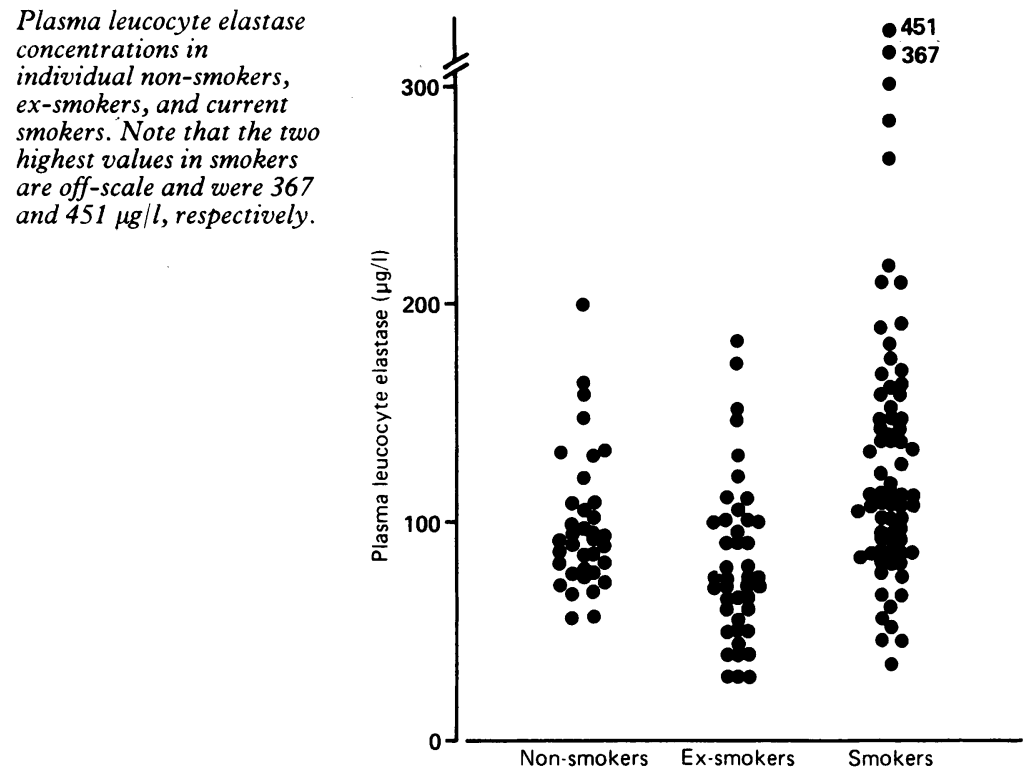

corrected $\mathrm{FEV}_{1}$ (table) than non-smokers $(\mathrm{p}<0.001)$ and ex-smokers $(\mathrm{p}<0.01)$.

PLASMA ELASTASE CONCENTRATION, LEUCOCYTE COUNT, AND LUNG FUNCTION CHANGES

There were no significant correlations between plasma elastase concentration or leucocyte count and current $\mathrm{FEV}_{1}$ or annual decline in $\mathrm{FEV}_{1}$ in any of the three groups of men (all $\mathrm{p}$ values $>0.3$ ).

\section{Discussion}

In this study we found that on average cigarette smokers had a significantly higher circulating concentration of leucocyte elastase than either non-smokers or ex-smokers. This increase could not be accounted for by the presence of a coincident infectious disease, because serum $\mathrm{C}$-reactive protein was normal in most subjects.

We took care to handle the blood specimens so as to avoid in vitro release of elastase from white cells; others have shown that plasma elastase values remain stable in vitro over one hour, provided coagulation is avoided. ${ }^{17}$ Furthermore, we found no correlation between the plasma elastase concentration and peripheral leucocyte count in smokers, even although, as previously shown by several groups, ${ }^{23}$ their leucocyte count was also raised. We aimed to study typical diurnal values in our subjects and made no attempt to control their preceding smoking history, although details of this were obtained for the hours before venesection. Although diurnal variation in plasma elastase has not been shown, rises in plasma elastase in an individual smoker have been shown after a period of particularly intense smoking, ${ }^{12}$ which is also associated with an acute rise in blood neutrophil counts. In our study, however, there was no relation between mixed expired carbon monoxide, a marker of the recent smoking history, and plasma elastase concentrations. None of the smokers with expired carbon monoxide of $>20 \mathrm{ppm}$ had elastase concentrations above $160 \mu \mathrm{g} / \mathrm{l}$; the 15 highest values of elastase were found in smokers whose expired carbon monoxide was less than $17 \mathrm{ppm}$. The mechanism of increase in the neutrophil count in smokers is not known, though a significant relation between the peripheral leucocyte count and the plasma nicotine concentration has been reported. ${ }^{18}$

Similarly, no correlation was found between the plasma elastase concentration or leucocyte count and abnormalities in lung function (as assessed by annual change in $\mathrm{FEV}_{1}$ over the preceding 10 years, or current percentage predicted $\mathrm{FEV}_{1}$ ). Although few of the men had values of $F E V_{1}$ definitely below the normal range, annual decline of $\mathrm{FEV}_{1}$ in the preceding years had been faster in the smokers than in non-smokers.

The finding of increased circulating leucocyte elastase in some smokers may be relevant to the induction of lung damage caused by smoking which is known to vary greatly among smokers. Activated neutrophils act both as effector cells of tissue damage and as amplifiers of the inflammatory process. Their azurophil granules contain a spectrum of proteinases capable of degrading the structural components of the interstitium-elastin, collagen, proteoglycans and basement membranes. $^{7}$ The generation of free radicals by these cells may also cause tissue damage either directly by lipid peroxidation, or indirectly by inactivation of the enzymes that normally protect against proteolytic damage, such as $\alpha_{1}$ proteinase inhibitor, antileucoprotease. ${ }^{71920}$ Cigarette smoke itself may induce an elastase$\alpha_{1}$-proteinase imbalance by directly inactivating elastase inhibitors. ${ }^{21}$ Thus Weitz et $a l^{2223}$ recently reported a large increase in fibrinopeptide $A-\alpha-1-21$ in the peripheral blood of cigarette smokers compared with non-smokers. Because this fibrinogen-derived peptide is apparently only cleaved by human neutrophil elastase, these authors used concentrations of this peptide for another assay of in vivo release of neutrophil elastase into the plasma. ${ }^{223}$ Bridges et al found increases in myeloperoxidase activity within peripheral blood neutrophils in young male smokers compared with non-smoking controls ${ }^{24}$; in these studies increased myeloperoxidase activity was not related to numbers of peripheral blood neutrophils, current lung function, or number of cigarettes smoked. Superoxide production by peripheral blood neutrophils was increased in smokers compared with non-smokers ${ }^{25}$ and superoxide production by blood leucocytes has been related to the degree of bronchial hyperresponsiveness in those with chronic airways obstruction. ${ }^{26}$ Although there was no relation between plasma elastase concentrations and the degree of abnormality in lung function in any of the groups we studied, the site of tissue damage and potential release of elastase is the lung interstitium ${ }^{27} 28$; we have investigated only the peripheral blood. Further studies are required to establish the clinical importance of the present findings for the development of lung tissue damage in smokers.

This work was supported by a grant from the Medical Research Council (G8404057SA). 
1 Auerbach O, Hammond EC, Garfinkel L, Benante C. Relation of smoking and age to emphysema: whole-lung section study. N Engl J Med 1972;286:853-6.

2 Howell RW. Smoking habits and laboratory tests. Lance 1970;ii:152-3.

3 Yeung MC, Buncio AD. Leukocyte count, smoking and lung function. Am J Med 1984;76:31-7.

4 BAL cooperative group steering committee. Bronchoalveolar lavage constituents in healthy individuals, idiopathic pulmonary fibrosis, and selected comparison idiopathic pulmonary fibrosis, and selected
groups. Am Rev Respir Dis 1990;141:S177-8.

5 Kilburn KH, McKenzie W. Leukocyte recruitment to airways by cigarette smoke and particle phase in contrast to cytotoxicity of vapor. Science 1975;189:634-6.

6 Reilly CF, Travis J. The degradation of human lung elastin by neutrophil proteinases. Biochim Biophys Acta 1980 621:147-57.

7 Janoff A. Elastase in tissue injury. Ann Rev Med 1985; 36:207-16.

8 Abboud RT, Johnson AJ, Richter AM, Elwood RK. Comparison of in vitro neutrophil elastase release in nonsmokers and smokers. Am Rev Respir Dis 1983;128: 507-10.

9 Blue M-L, Janoff A. Possible mechanisms of emphysema in cigarette smokers. Am Rev Respir Dis 1978;117:317-25.

10 Janoff A, Raju L, Dearing R. Levels of elastase activity in bronchoalveolar lavage fluids of healthy smokers and nonbronchoalveolar lavage fluids of healthy smokers
smokers. Am Rev Respir Dis 1983;127:540-4.

11 Neumann S, Heinrich N, Gunzer G, Lang H. Enzymelinked immunoassay for human granulocyte elastase in complex with alpha $a_{1}$-proteinase inhibitor in plasma. J Clin Chem Clin Biochem 1981;19:22-3.

12 Abboud RT, Fera T, Johal S, Richter A, Gibson N. Effect of smoking on plasma neutrophil elastase levels. J Lab Clin Med 1986;108:294-300

13 Fagan EA, Dyck RF, Maton PN, et al. Serum levels of C-reactive protein in Crohn's disease and ulcerative colitis. Eur J Clin Invest 1982;12:351-9.

14 Shine B, de Beer FC, Pepys MB. Solid phase radioimmunoassays for human C-reactive protein. Clin Chim Acta 1981;117:13-23.

15 Pepys MB, Baltz ML. Acute phase proteins with special references to C-reactive protein and related proteins
(pentraxins) and serum amyloid A protein. Adv Immunol (pentraxins) and seru

16 Quanjer PH. Standardized lung function testing. Bull Eur
Physiopathol Respir 1983;19(suppl 5):7-10

17 Plow EF. Leucocyte elastase release during blood coagulation. A potential mechanism for activation of the alternative fibrinolytic pathway. $J$ Clin Invest 1982;69:564-72.

18 Taylor RG, Woodman G, Clarke SW. Plasma nicotine concentration and the white blood cell count in smokers. Thorax 1986;41:407-8.

19 Dormandy TL. Free radicals in medicine. In: Triger DR ed. Advanced Medicine 22. London: Ballière Tindall, 1986:333-9.

20 Kramps JA, van Twisk $\mathrm{CH}$, Klasen EC, Dijkman JH. Interactions among stimulated human polymorphonuclear leucocytes, released elastase and bronchial nuclear leucocytes, released elastase and

21 Pryor WA, Dooley MM, Church DF The inactivation of alpha, -proteinase inhibitor by gas-phase cigarette smoke: protection by antioxidants and reducing species. Chem 1986;57:271-83.

22 Weitz JI, Crowley KA, Landman SL, Lipman BI, Yu J. Increased neutrophil elastase activity in cigarette smokers. Ann Intern Med 1987;107:680-2.

23 Weitz JL, Landman SL, Crowley KA, Birken S, Morgan FJ Development of an assay for in vivo human neutrophil elastase activity: increased elastase activity in patients with alpha -proteinase inhibitor deficiency $J$ Clin Invest 1986;78:155-62.

24 Bridges RB, Fu MC, Rehm SR. Increased neutrophil myeloperoxidase activity associated with cigarette myeloperoxidase activity associated with cigarette
smoking. Eur J Respir Dis 1985;67:84-93.

25 Ludwig PW, Hoidal JA. Alterations in leukocyte oxidative metabolism in cigarette smokers. Am Rev Respir Dis metabolism in ci

26 Postma DS, Renkema TEJ, Noordhoek JA, Faber H, Sluiter $H J$, Kauffmann $H$. Association between non-specific bronchial hyperreactivity and superoxide anion production by polymorphonuclear leukocytes in chronic air-flow obstruction. Am Rev Respir Dis 1988;137:57-61.

27 Kramps JA, Franken C, Dijkman JH. Quantity of anti-

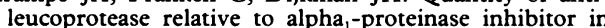
peripheral airspaces of the human lung. Clin $S_{c i} 1988$; 75:351-3.

28 Burnett D, Afford SC, Campbell EJ, Rios-Mollineda RA Buttle DJ, Stockley RA. Evidence for lipid-associated serine proteinases and metalloproteases in human bronchoalveolar lavage fluid. Clin Sci 1988;75:601-7. 